\title{
Constructing identities: Professional use of eID in public organisations
}

Elin Wihlborg, Mariana S Gustafsson, Fredrik Söderström and Karin Hedström

The self-archived postprint version of this journal article is available at Linköping University Institutional Repository (DiVA):

http:// urn.kb.se/ resolve?urn=urn:nbn:se:liu:diva-120124

N.B.: When citing this work, cite the original publication.

Wihlborg, E., Gustafsson, M. S, Söderström, F., Hedström, K., (2015), Constructing identities: Professional use of eID in public organisations, Transforming Government, 9(2), 143-158. https:// doi.org/ 10.1108/TG-11-2013-0049

Original publication available at:

https:// doi.org/ 10.1108/TG-11-2013-0049

Copyright: Emerald

http:// www.emeraldinsight.com/ 


\section{Constructing identities - professional use of eID in public or- ganisations}

Hedström Karin, Wihlborg, Elin, Gustafsson, Mariana, Söderström, Fredrik

Transforming Government: People, process, policy, 2015, Vol. 9, Issue, 2, pp. 143 - 158

\section{Introduction}

Systems for electronic identification (elD) are viewed as important back-office enablers for 'robust, streamlined and sustainable' e-government services (European Commission, 2010). But it also has implications for improved safety in public e-services used by citizens. Thus, elDs are viewed as a way of realising e-government policies, and making citizens' contacts with governments in EU countries more efficient, reliable, and secure (Melin et al., 2013). Individual states within the EU have issued more than 22.5 million elDs to their citizens (Collings, 2008), which serves to illustrate how different technologies and systems for electronic identification are becoming increasingly important, not only on the EU level, but also nationally (European Commission, 2010).

This strong trend can also be found on an organisational level, where elDs are used in different professional contexts; when issued by an employer, they ensure the identification of a specific employee. Thus, electronic identification is not only available and used for solving personal identity issues, but is also used for the purpose of identification, authentication, and providing signature in professional roles. Companies and government organisations can issue elDs to their employees in order to sustain information systems that are secure and efficient. In these situations, elDs can be seen as a tool for realising business goals and ensuring managerial control. They can also be seen as a prerequisite for ensuring information security. The reasons for using elDs, and the benefits sought after, are thus no different on an organisational level than they are on an EU level.

New information systems, such as elDs, change administrative practices (Fountain, 2001). Implementing an eID is therefore far more than a technical implementation. Whilst technology is often the driving force of eGovernment initiatives (Irani et al., 2007), social, political, and organisational effects are often even more prevalent. As such, an elD cannot be viewed as an isolated artefact; rather, it is part of a larger socio-technical arrangement (Latour, 1991, Law, 1992) where social and technical aspects are intertwined and insepa- 
rable. Often, probably out of simplicity, we refer to elDs as an artefact, a 'thing' (Whitley and Hosein, 2010). In so doing, we ignore its extensive and underlying political and organisational arrangements, as an eID includes both the effects of the socio-political and organisational context and the heterogeneous network (Latour, 1987).

However, previous research on elDs has mainly focused on the technology involved (Melin et al., 2013). Thus, there is a need to improve our understanding of how electronic identification, as a socio-technical arrangement, is implemented in organisational contexts. In particular, it is necessary to focus on more context-specific research of elD in practice to 'gain a better understanding of the identity domain' (Halperin and Backhouse, 2008), and to carry out an analysis of the implications for individuals and organisations.

The meaning of 'identity' 'encompasses each of the multiple roles that a person plays' (Clarke, 2008). The interpretations of a digital identity are related to the different roles played by one person. When an eID is introduced into the workplace, there is thus an ongoing co-construction of roles, as well as identity. This paper aims to reveal how identities are constructed when elDs are introduced through information systems in public organisations. This article will focus on, and be structured around, two main research questions:

- How is identity constructed through the introduction and use of of elD? - Why do different professional roles imply different uses of elD?

Our study is based on two qualitative case studies in local public service organisations. In particular, we show how contradictory practices have emerged in spite of basic similarities. Our analysis, based on Actor Network Theory (ANT) (e.g., Latour, 1987, Law, 1992), focuses on introduction and use as a process of translation (Latour, 1991) of elDs in these two settings, where the meanings of eID are formed through the interactions within networks of actors and artefacts.

This paper is structured as follows. A research overview and background is presented in Section Two. This is followed in the third section by our theoretical framework. In Section Four we present our research approach, together with a description of our cases. In Section Five we use the concept of translation to reveal how elDs construct identities in public organisations. Finally, in the sixth section, we present our conclusions. 


\section{Electronic identification and public organisations - a re- search overview and background}

The concept of 'identity' is not only heterogeneous, but is also used in contradictory ways; in other words, 'pointing in sharply different directions' (Brubaker and Cooper, 2000). Digital identity, in the form of an identity management system such as an elD, can be seen as the virtual presentation of a human entity (Clarke, 2008). The focus of different types of identity management systems is on identification, i.e., where you place yourself in one specific category (Brubaker and Cooper, 2000).

Research on identification and identity can be found in a variety of research areas. Some studies have focused on identification (e.g., Bose et al., 2009, Seltsikas and O'Keefe, 2010), whilst others have examined organisational and personal identity (e.g., Adam et al., 2006, Gal et al., 2008) or identity management (e.g., Kubicek, 2010). Several examples of Scandinavian studies about elDs have been published. For instance, Hoff and Hoff (2010) studied the development of the Danish elD. Another Scandinavian elD initiative was presented in a study by Rissanen (2010), who studied the introduction and diffusion of the Finnish Electronic Identity (FINEID) card. Grönlund (2010) researched Swedish elD and concluded that the Swedish eID case was a fairly complex solution based on a market approach. As such, it lacked central governance but had a good service supply and use.

An elD can be seen as a type of a 'token', in the form of hardware or software, which contains credentials based on specific attributes (Kubicek, 2010). This 'token' can be in constructed as a digital data set, as a smart card or embedded in mobile phones (Kubicek, 2010). Commonly, elD solutions are presented in the form of an elD-card, with a password, and/or as a box where the user can enter a digital code in order to access a secure site or service.

Traditional ID cards, which are based on citizenship, are still the most common, although many government authorities and businesses have been issuing cards for electronic identification (i.e., smart cards) for some time now. Flexible options can also be added in the form of additional elD-card services when in use. Citizens have several reasons for requesting elDs; in particular, they can use them to access services issued by the government, or to carry out certain tasks, such as on-line banking. Here, the elD becomes an artefact where interlinked multiple roles come into play, opening the way for constructions of new meanings. 


\section{Actor Network Theory and electronic identification}

ANT is a process-oriented theory that follows the constructions of associations within the network. One key feature of ANT is that it does not make an a priori distinction between human and non-human actors. Both are viewed as active makers of actor networks and are included in the unifying actant concept. Furthermore, networks are changed through translation. A translation is the establishment of a new or changed relation between actants, and can be described as coexisting in a network to achieve a common goal. The translation model refers to the prioritisation of interests, which means that 'things' (e.g., artifacts, orders, goods) are 'in the hands of people; each of these people may act in many different ways, letting the token drop, or modifying it, or deflecting it, or betraying it, or appropriating it. [...] Each of the people in the chain is [...] doing something essential for the existence and maintenance of the token [...] and since the token is in everyone's hands in turn, everyone shapes it according to their different projects' (Latour, 1986). Translations require enrolment; a process formed through power relations since actants seek to influence each other to shape the network and act within that network. As Walsham (1997) has noted, 'successful networks of aligned interests are created through the enrolment of a sufficient body of allies, and the translation of their interests so that they are willing to participate in particular ways of thinking and acting which maintain the network'. The networks are formed by a complex set of actors that together reframe inputs through unpredictable processes into its new contexts. Hereby, the meanings of knowledge can be translated to fit into the receiving context and make a difference in the new setting (Latour, 2005). Translation changes meanings and content, and makes different actors connect within the network. In translation, different actors or actants actively seek ways to persuade or convince others to share their beliefs and thereby align themselves with the network (Callon, 1986). Enrolment and translation can lead to inscriptions in the artefact (Akrich, 1992), where different interests are inscribed into written material or technical systems. The artefact embodies patterns of use (Monteiro, 2000), and in a way constructs the user through choices of functionality that hinder or restrict the users' actions. In order to create authority, allies that support a body's interests and roles are enrolled. These can be seen as gatekeepers, or obligatory passage points (Star and Griesemer, 1989, Callon, 1986).

\section{Research design}

The aim of this paper is to reveal how professional identities are constructed when elDs are introduced through information systems in public organisations. Thus, we have chosen to use an interpretative approach (Alvesson and Sköldberg, 2009). Our analysis is based on two in-depth case studies (Yin, 1994), which generate rich data on the con- 
struction of professional elDs within public organisations. The cases were selected from a variety in the field of welfare services (health care and elementary education), as well as types of elD system used. The case studies took place in the extensive Swedish welfare state, where the citizens generally express high trust in public services and a willingness to share information (e.g., Rothstein et.al. 2012). The cases are similar enough to allow comparisons to be made, but are still different enough to provide triangulation on different levels (Patton, 1990). Both cases relate to public organisations that provide welfare services, where professionals use elD to access and register information regarding 'clients' (see Table 1). Data collection varies in both cases. These differences are mainly based on how the service is organised, and the types of respondents (see Section 3.2).

Key characteristics of the two cases, and any differences, are described in Table 1 below. As illustrated, the two cases differ in terms of the type of elD solution, the services provided, the organisational model, and the key drivers for eID implementation. This diversity has led to several interesting differences in the way eID is translated in the two cases.

Table 1. Key characteristics of the cases

\begin{tabular}{|l|l|l|}
\hline & $\begin{array}{l}\text { Health care professionals in the } \\
\text { county council }\end{array}$ & $\begin{array}{l}\text { Teachers in public and free } \\
\text { schools }\end{array}$ \\
\hline $\begin{array}{l}\text { Type of elD solut- } \\
\text { ion in the organi- } \\
\text { sation }\end{array}$ & Employee elD-card & User-ID and password \\
\hline Services provided & Health care & Elementary education \\
\hline $\begin{array}{l}\text { Organisational } \\
\text { model }\end{array}$ & $\begin{array}{l}\text { One large coherent organisation } \\
\text { with a centralized decision-model } \\
\text { for the implementation and use oftation and put into practice their } \\
\text { electronic platforms }\end{array}$ & $\begin{array}{l}\text { High level of autonomy for each } \\
\text { school to design their implemen- }\end{array}$ \\
\hline $\begin{array}{l}\text { Key drivers for elD } \\
\text { implementation }\end{array}$ & $\begin{array}{l}\text { Secure strong authentication of } \\
\text { patient data according to the Pa- } \\
\text { tient Data Act (PDA) }\end{array}$ & $\begin{array}{l}\text { Legislation regarding improved } \\
\text { communication between schools } \\
\text { and homes }\end{array}$ \\
\hline
\end{tabular}

\subsection{Case descriptions}

In Sweden, the national elD model has emerged in close interplay with a technical solution developed by the banking sector. Since 2000, the government has used and relied on a market-based model for public e-government services for citizens and businesses (Söderstrom and Melin, 2012). Swedish work with identity management has been seen as part of an attempt to implement secure and efficient e-government. When the eID 
model needed to be renewed in 2010, an investigation was launched with the aim of designing the next generation of the national elD model (eID 2.0). As a result the investigation suggested the establishment of a public authority with the main purpose of coordinating the development of the new eID solution. Accordingly, the eID Board was formed in 2011 (SOU, 2010:104). The professional and private use of the elD solution is based on the same technical solution, meaning that the same issuing process can be used for both types of elD. In both cases, the user is personally responsible for the eID, and the elD system can be used for both professional and private tasks, such as bank services and purchases.

In Sweden, e-government policies and practices have developed in relation to the extensive welfare state and far-reaching public services. The implementation of public services is today framed through new public management models of governance and a high level of local autonomy for municipalities (Montin and Granberg, 2013). The cases included here were conducted in public schools and health care facilities. The schools are managed by municipalities and organised through a consumer choice model; free-schools ${ }^{1}$ are also included. Public health care is managed through the county councils and there are also forms of patient choice regarding primary health care.

In the health care case, an elD-card is used to access and register information about patients. The county council, as the employer, provides employees with elD-cards. The key driver to implementing the eID was to secure strong authentication of patient data according to the Patient Data Act. The organisation is managed both hierarchically, mainly in hospitals, and with local arrangements in health care centers. However, since all units use the same Electronic Patient Record system, there is a high demand for similar approaches to this system where eID is key. The county council case focuses on a project aimed at the organisation-wide introduction of an eID for professional use within health care. This case study was carried out in a Swedish county council that represents some 434,000 citizens. The project was initiated in 2012 and driven by an urgent need to comply with the PDA (Patient Data Act) and NBHW's (National Board of Health and Welfare) regulations issued by the hospital management. This project takes place within a heterogeneous organization and is wide ranging, in terms of IT systems, organization, and types of users. The number of potential users is 14,000 . Furthermore, the project team estimates that the elD-card would work for accessing patient data in approximately $75 \%$ of the IT system, including patient data. For the remaining $25 \%$ of IT systems, a different

\footnotetext{
${ }^{1}$ Free schools provide education at primary and secondary levels, are run by private companies or associations, follow the same laws and regulations as the public schools and are financed through public funding. The municipality has the main responsibility to allocate pupils and resources to the free schools.
} 
solution is needed. In addition, there have been compatibility and scaling problems. Consequently, the chosen technical solution has also 'forced' other systems (e.g., the software handing of the payroll), to become part of the eID project, because their use is based on the same technical platform used to handle patient data.

The role of the elD was mainly to ensure secure access to patient data. However, in order to promote usage, the management also wanted to include access to different types of private and professional services, such as access to parking, doors, printers and copier machines. They also wished to use the eID as a payment tool for other items, such as coffee or lunches. The management also stressed that the eID can be used as a private ID for accessing, for example, banking services, or making on-line purchases.

In the elementary education case we followed the use of eID within public schools. Here, it is used for registering and accessing information on pupils and for enabling communication between homes and schools. To date, elD is offered and practiced as a log-in alternative to the systems for parents only. However, its use for further administrative tasks to be carried out by school personnel is currently under consideration by the municipality. Schools have a high level of autonomy regarding their organisation. This gives them the opportunity to decide which IT systems they will use, and how. The key driver for implementing eID within schools was to conform to legislation regarding improved communication between schools and homes for the purposes of planning and monitoring pupil progress (Education Act 2011).

The case study of eID in schools was placed in the context of IT platforms that have been developed for pedagogical issues as well as for communication between schools and homes with regard to pupils' progress and plans. The case study was conducted in the Linköping municipality (150,000 inhabitants). In accordance with the Education Act the teachers are obliged to draft and communicate an individual study plan for each pupil in each subject, once a year. Thus there is a need for a simple and safe communication system between homes and schools, and there is a need for teachers to be able to log-in and provide and manage safe personal information regarding their pupils.

Several IT systems were in use among the studied schools, but they were not clearly related. The main platforms were FRONTER, DEXTER and SKOLA 24. All three offer similar functions in the administration of education; however, the schools differ in their frequency and range of use of the platforms. There was no coherent strategy regarding the use and type of IT systems, but all schools had an expressed policy to improve and extend the use of the systems. The use of IT in schools has a long history and appears to be of high symbolic value for the municipality. There has been a rapid growth in the number of users on the platforms, in spite of their de-centralized implementation and lack of 
coherence. With regard to FRONTER, between September 2005 and September 2012, the number of active users rose from 338 to 6,865 (Gustafsson and Wihlborg, 2013). This development has been rapid and there has been a pressure, both from the political management of the municipality and parents, to further improve and extend the IT systems. However, the introduction of new IT platforms in schools with high budget constraints added to demands on the teachers and schools. The technical solution was based on the parents using their own private eID to access the IT systems and take part in pupil-related communication.

\subsection{Data collection}

This is a qualitative study, where the empirical material is mainly based on interviews with eID users. The role of the interviews was to generate rich data on the implementation and use of elD within the studied organisations (Schultze and Avital, 2011). The interviews provided concrete examples, motives, and explanations that illustrate the complexity of openness for the translation of eID. In the health care case, this complexity was confirmed through observations of how the eID is used in practice. In the school case, the interviews were complemented with focus group interviews (Kitzinger, 1994). The use of focus groups made the number of respondents higher in the school case, compared to the study in the hospital.

In order to capture the diversity of issues related to the implementation and use of elD within the county council, we chose to collect data from one hospital ward and one health center within the county council. This made it possible for us to capture users' experiences of the implementation project and the use of eID for health care work. The two health care organisations differed in terms of how long they had used eID, and the type of health care provided. The health care case included twelve interviews with highlevel managers and project leaders in charge of the elD-implementation project, staff using the eID within their health profession, and IT-support personnel with extensive experience about problems that might arise from the use of eID. In addition, on two occasions we came back and interviewed two of the respondents in order to ask some follow- up questions. The purpose of the interviews was to get a better understanding of the drivers behind the implementation project, the functionality and use of the eID, as well as the problems and benefits of using eID. The interviews were complemented with our observation of how administrative health care staff uses their elDs.

For the school case, we combined individual interviews with focus group interviews. Focus groups are organised around a specific theme, or set of questions, for example, to discuss and explore a specific issue (Kitzinger, 1994). Focus groups allowed us to carry out more in-depth studies on the translations of elD. Another important contribution of focus groups is the knowledge that develops among the participants because of the in- 
teraction that occurs during focus group work. Based on a mapping of the 'history of use' of IT platforms by all 56 schools in the municipality, including public and private schools (managed as "free schools" with full public funding), seven schools were selected for in-depth case studies. In total, 18 interviews and 9 focus groups, involving 55 participants (school principals (4), teachers (17), schools' platform administrators (2), pupils (13), parents (11) and municipality officials - users of platforms (8)), were the main sources of empirical data. The research design strived to reach key participants who could tell their eID translation stories.

\subsection{Data analysis}

Contrasting the two cases allowed us to present our analysis and its implications. We were also able to highlight the various ways that eID can be translated, which opens the way to different constructions of identity. We view introduction and use of elD as a process of translation, where the different interpretations of the eID are formed through interactions within networks of actants and artefacts. Our analysis has thus been based on ANT (Latour, 1987, Law, 1992) and structured around the two research questions: 1. How is identity constructed through the introduction and use of elD? 2. Why do different professional roles imply different uses of elD? ANT is often used for analysis (Walsham, 1997) when researchers want to see beyond the obvious, and make the events leading up to a result both visible and possible to discern.

The two contrasting cases offer a rich and varied picture of the use and translation of eID in relation to identity. Our analysis was conducted in two steps. First, we analysed each case separately in order to disclose how identity was constructed in the context of the specific case. In line with ANT, we identified how the elD was used and what for, and the functionality it included from the perspective of the different respondents in each case. Second, we used the results from the analysis of the separate cases to provide contrasting stories, where the results of one case guided us in the analysis and interpretation of the other. This helped us to unfold the translation process and the different mechanisms that come into play.

\section{5. elD and the construction of identity}

Based on ANT, the results reveal how elD enters an organisational context and is translated into the organisational setting, culture and context. From this perspective, the eID is given meaning through the way in which it is integrated in the specific organisation, and also the construction and re-construction of identity. The results are presented in response to the two research questions. 


\subsection{How is identity constructed through the introduction and use of elD?}

The county council's elD-card has, in the health care setting, become an obligatory passage point for accessing digital information. Without elD, it is not possible to access patient data, or indeed other types of information. Here, one can identify two roles: project initiators or drivers, and users. For initiators it is clear that the role of the elD-card is to 'solve the requirement for strong authentication' (information security manager) in order 'to follow the Patient Data Act' (project leader). The users see the elD-card as: '... an ID I use in my work' (manager of health care unit), and, 'Well, what is this thing? It is an identification of who I am' (nurse aid). As illustrated by the above quotes, the users see the elD-card as an identifier or as a tool for safeguarding sensitive patient data, which to a degree is similar to the meanings attributed by the project initiators. However, as the card has been implemented and translated into the network, these meanings have changed. Thus, in order to enrol more users, project initiators have tried to add functions to the card which are outside the scope of the eID project and the initial need for secure access of sensitive patient data. There are, for instance, arguments that using the elDcard for purchasing coffee, accessing doors and the parking lot would 'force' the employees to always carry and use the elD. Thus, management envisioned that the professional elD-card would be used by the employees not just for work, but also as a personal identity card. This card would be used to access e-services linked to their roles as private individuals at work, or for accessing other types of private services outside work. There are, however, some users who do use their professional elD-card as personal elD: 'I know a few who use it as ID for the tax authorities and other things'. However, most users we met were very critical of private use of the professional elD. As one user stated: 'I do not use this card for personal use. Only for work'. Indeed, this seems to be a typical way of viewing the elD-card; it is for professional use only. Another user was very clear when she raised concerns about the idea of using the eID as a key card, as she then has to take the eID home with her in order to lock the door and to get into work the following morning: 'I think the largest protests will come if they include the key card on the elDcard. If you forget to bring that card with you home in the evening, you won't be able to enter the building in the morning when you arrive to start work'.

The health care organisation has a history of continuous development and changes regarding their IT systems. Consequently, we found that there was some resignation and fatigue regarding IT implementation among the employees. With regard to the reason for implementing the eID, one nurse told us: 'I guess it has to do with security. I do not understand why I say that. One always does as they [management] say. First you should do this way, and then that way. I do not think it feels safer. It is the same. The only difference is that I have to use the card, without it I cannot access the information'. 
Some of the users at the clinic and on the ward support the use of eID, while others are more or less openly resistant. According to IT support staff, many users leave their eIDcards in the computers when they go for short breaks. One employee stated that: 'We do not handle this properly, from a patient security point of view; we don't take out the card, we don't lock the doors. Many leave the doors unlocked, and the cards in the computers. Anyone could get access'. Another way of 'resisting' is the use of workarounds. The IT department discovered that some users had found a way to access patient data without using the elD-card: 'They access patient data through the back door. They don't use the eID-card. And then there is no patient security'. The health care organisation saw the implementation of an eID card as a way of meeting the statutory requirements of strong authentication for accessing patient data. However, this requirement cannot be met without using the elD-card, or when the elD-card is handled in a manner that may lead to security breaches. Nurses, nurse-aids, and administrators practice this type of concealed under-the-cover resistance, while the physicians tend to express their concerns more openly. The latter also had a notable effect, leading to changes and improvements.

The main impression from the school case is that teachers are hesitant to use their private eID for accessing and registering work-related information, if required to do so. The teachers would thus have to combine the networks of private practice and individual elD to enable them to function in their professional networks and fulfil the assignments given by their employers. The teachers raised this as a problem as they want to have, and uphold, a clear separation between their private and public identity. During a focus group interview we were told the following: 'It is important to have a specific elD for the school, so that one doesn't use his or her own private elD. This is not ok. I am also a parent to a pupil at another school and they want us to use eID for log-in. But I have no wish to do it. I would never log-in with my personal number, my private elD. I have no interest in doing it. Absolutely not. It's my private eID, which I use to pay my bills or buy something on the internet... It is another thing to log-in with the teacher eID, instead of with the private eID. It's unacceptable! Would you log in with your private elD at your university?'. This clearly indicates a hesitation to be enrolled into the network.

When teachers were asked about the option to use their private elD to log in to the platforms, they were hesitant about using their elD at work. Their private eID was seen to be on a par with other private and valuable documents, such as passports; these sorts of documents are used for proof of identity in such areas as internet banking, filing a tax declaration, and making applications for social welfare (e.g., sick leave, parental leave). Using private eID at work was unthinkable for those people who connected it with the possibility of someone else logging in and controlling an individual's information and the fear of making the data linked to the elD available to employers and other actors; for 
example, state agencies could gain access to the data connected with elD use at work. In this sense, the elD can be seen as a 'key' that can open more and more doors to citizens' information and activities for the state agencies, as well as other, non-state actors.

In the school case, both management and teachers resisted this way of accessing and registering information about pupils. However, the lack of internal arrangements for elD in the schools meant delays for other teachers' assignments. A network and improved arrangements for promoting eID would also promote other processes in the daily work in the schools.

\subsection{Why do different professional roles imply different use of elD?}

In this study, we compared the two studied translation processes of elD in order to focus on how elD is interpreted as an object connected with the professional role. The ways that eID is translated reflect how the professional role is constructed within the organisation. Both the private and professional roles are embodied in the eID system, thus constructing the identity of its user and how, and to what degree, the private or public roles are mixed and constructed.

In the school case, the users clearly wanted to uphold the separation between private and professional roles. The health care case illustrated how, even if a professional elDcard was issued, management saw private use of the elD-card as a way of motivating work-related usage. Health care professionals, especially physicians, have a high status, and it is considered important to acknowledge health care as a professional activity carried out only at hospitals or health care centers. However, teaching, although considered a professional activity, comes with a less clear division between home and school. Moreover, teachers have a lower status than, for instance, physicians. There is indeed a power relation between the employees and their organisations, which frames if and how private eID is used, or if an organisational specific elD is developed and used.

A culture exists in which many teachers buy their own teaching materials or extras such as pedagogical games. This may be one explanation as to why the construction of identity and the boundary between professional and private roles are viewed so differently in these two cases. The translation of eID in schools is very much grounded in the culture of schools and the teacher's own practices. Indeed, the classroom is widely regarded as an almost private sphere of the teacher. In line with such ideas, eID is constructed as an attribute of the single teacher rather than the organisation of the school.

Our comparison of the two cases left us with the impression that the health care organisation aimed to extend the use of the employer's identification system. By way of contrast, the schools demanded that parents use their private eID, based on their private 
relations with banks. These different constructions of identity are the main focus of our analysis.

\section{Conclusions}

The aim of this paper was to reveal how identities are constructed when elDs are translated through e-government information systems in public organisations. We saw how the organisational setting, even in two public organisations, has the capacity to form local translations of elDs. A comparison of these two cases apparently indicates that the division of private and public aspects of people's identity and the management of it can indeed differ. Meanings and values are embedded within the technological artefacts, where the eID becomes a key actor or even a gate-keeper for constructing and materialising identity. The use of electronic identification systems issued by employers can influence the individual both in their role as a citizen and in their professional role, because personal benefits, such as adopting elD for private use, are often integrated in the professional elD-card solution. Hence, electronic identification can be viewed as an artefact at a point where the public and private spheres meet.

Despite contrasting ambitions on how to manage elD, in both cases the professions were clearly uncertain as to how and why they should mix private and professional use of eID. In the health care case, the nurses were resistant to adding private services to their professional elD. In the school case, the teachers did not want to have to use their private elD in their professional roles and activities. Our analysis also showed that eID includes different types of routines; likewise, we identified variation in what is included in the network. The professional role related to eID is complex, and can include the private as well as the professional role. We found at least three mixed role dimensions in the use of elD: 1 ) as a purely private person, 2) as a private person in the work place, and 3) as a professional in the work place.

The different outcomes and un-coordinated use of elD, may be explained by the Swedish institutional system of extensive autonomy for local governments. This can impose difficulties when attempting to create a common technological platform. Thus we can conclude that the translation of eID is indeed dependent on the local organisation and the management of routines and work on different, but connected, organisational levels. The technical framing of the identification system appears to be subordinated to organisational arrangements and cultures. Thus, there is a need for further research on how elD is translated into organisational contexts and how institutional settings define the openings for local translation processes. We would especially welcome studies of elD use, as the power relations and resources of actors in organisations define how the artefact, as an elD, is interpreted and used. 
Since our results have been based on two limited case studies, meaning that broad generalisations are difficult to make. Nevertheless, we have seen that eID is so much more than technology; it touches upon something very profound and basic. It raises questions about who we are, who we want to be, and expectations about whom we should be. It also points at the more general importance to focus on translation processes when new meanings are formed and integrated into organisational arrangements. For trustworthy and legitimate development and use of elD we therefore have to take the question of identity seriously.

\section{Acknowledgment}

We are grateful to the Swedish Civil Contingency Agency for funding this research.

\section{References}

Adam, A., Griffiths, M., Keogh, C., Moore, K., Richardson, H., Tattersall, A. (206), "Being an 'it' in it: Gendered identities in it work", European Journal of Information Systems, Vol. 15 No. 4, pp. 368-378.

Akrich, M. (1992), "The De-Scription of Technical Objects", In: Bijker, W. \& Law, J. (eds.) Shaping Technology/Building Society. Studies in Sociotechnical Change. The MIT Press, Cambridge: MA, pp.205-224.

Alvesson, M. \& Sköldberg, K. (2009), Reflexive Methodology. New vistas for qualitative reserach, Sage Publications London, UK.

Bose, I., E.W.T, N., Teo, T. S. H. \& Spiekermann, S. (2009), "Managing RFID projects in organizations", European Journal of Information Systems, Vol. 18 No. 6, pp. 534540.

Brubaker, R. \& Cooper, F. (2000), "Beyond 'identity'", Theory and Society, Vol. 29, pp. 147.

Callon, M. (1986), "Some elements of a sociology of tranlsation: domestication of the scallops and the fishermen of St Brieuc Bay", In: Law, J. (ed.) Power, action and belief - a new sociology of knowledge? Routledge, London, pp. 196-223.

Clarke, R. (2008), "Dissidentity - The Political Dimension of Identity and Privacy", Identity in the Information Society Vol. 1 No. 1, pp. 221-228.

Collings, T. (2008), "Some thoughts on the underlying logic and process underpinning Electronic Identity (e-ID)", Information security technical report, Vol. 13 No. 2, pp. 61-70.

European Commission (2010), Digitizing Public Services in Europe: Putting ambition into action, 9th Benchmark Measurement. Directorate General for Information Society 
and Media, Unit C.4 Economic and Statistical Analysis [online]. Available: http://www.capgemini.com/resources/2010-egovernment-benchmark Fountain, J. (2001), Building the Virtual State: Information Technology and Institutional Change, Brookings Institution Press, Washington.

Gal, U., Lyytinen, K. \& Yoo, Y. (2008), "The dynamics of it boundary objects, information infrastructures, and organisational identities: The introduction of $3 \mathrm{~d}$ modelling technologies into the architecture, engineering, and construction industry", European Journal of Information Systems, Vol. 17 No. 3, pp. 290-304.

Grönlund, Å. (2010), "Electronic identity management in Sweden: governance of a market approach", Identity in the Information Society, Vol. 3 No. 1, pp. 195 - 211.

Gustafsson, M. \& Wihlborg, E. (2013), "Organizing safe on-line interaction and trust in governmental services. A case study of identification channels for public eservices in schools", JeDEM. The eJournal of eDemocracy and Open Government, Vol. 5, No. 1, pp. 155-173.

Halperin, R. \& Backhouse, J. (2008), "A roadmap for research on identity in the information society ", Identity of the information society journal Vol. 1 No. 1, pp. 1-16.

Hoff, J. V. \& Hoff, F. V. (2010), "The Danish elD case: twenty years of delay", Identity in the Information Society, Vol. 3 No. 1, pp. 155 - 174.

Irani, Z., Love, P. \& Montazemi, A. (2007), "E-government: past, present and future", European Journal of Information Systems, Vol. 16 No. 2, pp. 103-105.

Kitzinger, J. (1994), "The methodology of Focus Groups: the importance of interaction between research participants", Sociology of Health \& Illness, Vol. 16 No. 1, pp. 103-121.

Kubicek, H. (2010), "Introduction: conceptual framework and research design for a comparative analysis of national elD Management Systems in selected European countries", Identity in the Information Society, Vol. 3, pp. 5-26.

Latour, B. (1986), "The powers of association", In: Law, J. (ed.) Power, Action and Belief. Routledge, London, pp. 264-280.

Latour, B. (1987), Science in action: how to follow scientists and engineers through society, Harvard University Press, Cambridge, MA.

Latour, B. (1991), "Technology is society made durable", In: Law, A. J. (ed.) sociology of monsters: essays on power, technology and domination. Routledge, London, pp. 103-132.

Latour B. (2005), Reassembling the social, Oxford University Press, Oxford.

Law, J. (1992), "Notes on the Theory of the Actor-Network: Ordering, Strategy, and Heterogeneity", Systems Practice, Vol. 5 No. 4, pp. 379-393.

Melin, U., Axelsson, K. \& Söderström, F. (2013), "Managing the development of secure identification - investigating a national e-ID initative with a public service context", Paper 63. European Conference on Information Systems (ECIS), Utrecht, The Netherlands. 
Monteiro, E. (2000), "Actor-Network Theory and Information Infrastructure", In: Ciborra, C. (ed.) From control to drift: the dynamics of corporate information infrastructures. Oxford University Press. Oxford, pp 71-83.

Montin, S. \& Granberg, M. (2013), Moderna kommuner, Liber Stockholm

Patton, M. Q. (1990), Qualitative Evaluation and Research Methods, Sage Publications, Newbury Park, USA.

Rissanen, T. (2010), "Electronic identity in Finland: ID cards vs. bank IDs", Identity in the Information Society, Vol. 3 No. 1, pp. 175 - 194.

Rothstein, B., Samanni, M., \& Teorell, J. (2012), "Explaining the welfare state: power resources vs. the Quality of Government", European Political Science Review, Vol. 4 No. 1, pp. 1-28.

Schultze, U. \& Avital, M. (2011), "Designing interviews to generate rich data for information systems research", Information and Organization Vol. 21, No. 1, pp. 1-16.

Seltsikas, P. \& O'Keefe, R. M. (2010), "Expectations and outcomes in electronic identity management: The role of trust and public value", European Journal of Information Systems, Vol. 19, pp. 93-103.

Söderstrom, F. \& Melin, U. (2012), "The Emergence of a National elD Solution - an ActorNetwork Perspective", The 35th Information Systems Research Seminar in Scandinavia, August 17-20, 2012, Sigtuna, Sweden.

SOU (Official Government Report). (2010:104), E-legitimationsnämnden och Svensk elegitimation [Online]. Available: http://www.regeringen.se/sb/d/12840/a/158256.

Star, S. L. \& Griesemer, J. R. (1989), "Institutional ecology, 'translations' and boundary objects: amateurs and professionals in Berkeley's museum of vertebrate zoology ", Social studies of science, Vol. 19 No. 3, pp. 387-420.

Walsham, G. (1997), "Actor-Network Theory and IS research: Current status and future prospects", In: Lee, A. S., Liebenau, J. \& Degross, J. I. (eds.) Information systems and qualitative research. Published Chapman and Hall Place.

Whitley, E. \& Hosein, G. (2010), "Global Identity Policies and Technology: Do we Understand the Question?", Global Policy, Vol. 1 No. 2, pp. 209-215.

Yin, R. K. (1994), Case Study Research. Design and Methods, Sage Publications, Thousand Oaks. 